\title{
SPECIALISED DIPLOMAS: TRANSFORMING THE 14-19 LANDSCAPE IN ENGLAND?
}

\author{
Article submitted for consideration for publication in the Journal of \\ Education Policy
}

Ann Hodgson and Ken Spours

Institute of Education, University of London

20 Bedford Way

London WC1H OAL

Telephone numbers: 020-7612-6762 or 020-712-6384

Fax: 020-7612-6632

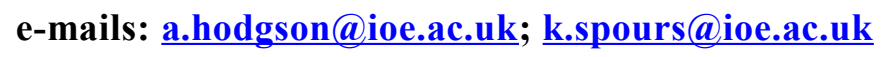

(this paper has not been published elsewhere) 


\title{
Specialised Diplomas: transforming the 14-19 landscape in England?
}

\begin{abstract}
Reforming vocational education in the English education and training system has occupied governments for at least the last three decades, the latest development being the introduction of 14 lines $_{i}$ of Specialised Diplomas. Using an historical analysis of qualifications reform, we suggest they are unlikely to transform 14-19 education and training. The failure to reform academic qualifications alongside their vocational equivalents is likely to result in 'academic drift' ${ }_{i i}$, lack of status and a relatively low level of uptake for these new awards, a process compounded by low employer recognition of broad vocational qualifications. In rejecting the Tomlinson Report's $s_{i i i}$ central proposal for a unified diploma system covering all 14-19 education and training, we argue that the Government may have condemned the Specialised Diplomas to become a middle-track qualification for a minority of 14-19 years olds, situated between the majority academic pathway and the sparsely populated apprenticeship route.
\end{abstract}




\section{Understanding and locating Specialised Diplomas}

Specialised Diplomas are the most recent qualifications policy initiative in the upper secondary English education and training system. We will argue that they are the latest in a long line of qualifications-based solutions to the deep-seated problem of raising the status of vocational learning in this country. The Government in England ${ }_{i v}$ is relying on the development of this new suite of vocational qualifications to lever up participation rates in the 14-19 phase and, in particular, at 17+. Specialised Diplomas are seen as the centrepiece of the national 14-19 Entitlement outlined in the 14-19 White Paper (DfES 2005a) and they are the principal reason given for why schools, colleges and work-based learning providers should collaborate (DfES 2005b). Using historical analysis and current data on Specialised Diplomas in the early phase of their design and implementation, we argue that these new qualifications are likely to function more effectively than predecessors, such as General National Vocational Qualifications (GNVQs), as a 'middle track' ${ }_{v}$ for full-time younger learners. Their position between a dominant academic track and apprenticeships will, however, in our view, inhibit Specialised Diplomas from becoming highly regarded and popular qualifications. The prospect of these awards making only limited headway in the middle track should be concerning for Ministers who hope that diplomas can be a transforming influence for the 14-19 education and training system as a whole (DfES 2005a). Or, put another way, Specialised Diplomas may make more of an impact than GNVQs, but they are unlikely to usher in a new dawn for vocational education in this country.

Our presenting argument is that the future of Specialised Diplomas, as broad vocational qualifications $s_{\mathrm{vi}}$, will be affected not only by supply-side features, such as their design, structure, content and assessment, important though these will be, but by issues of learner 
and end-user demand due to their location vis-à-vis established academic qualifications and sought-after employment-related experiences such as apprenticeships. Learner demand for these new qualifications is, therefore, likely to be reduced by the continuation of traditional A Levels and General Certificates of Secondary Education (GCSEs) and by the low level of employer demand for broad full-time vocational qualifications. These long-standing difficulties facing vocational qualifications in England mean that it is important to exercise what Higham and Yeomans (2006) refer to as 'policy memory' when assessing the potential impact of new initiatives in order to learn lessons from the past.

\section{Specialised Diplomas within their historical context}

The history of broad vocational qualifications in England spans more than two decades, but the debate about the function of a nationally recognised broad vocational track between academic A Levels and occupationally-specific National Vocational Qualifications (NVQs) only emerged after the publication of the 1991 White Paper (DfE/ED/WO 1991) with its proposals for the development of Foundation, Intermediate and Advanced GNVQ as part of a national triple-track qualifications system (Hodgson and Spours 1997). Other broad vocational awards existed prior to this (e.g. the Certificate of Pre-Vocational Education, the Diploma of Vocational Education and the Business and Technology Council (BTEC) National Diploma), but these were products of individual or joint awarding body initiatives rather than government-inspired national awards. Of these, BTEC diplomas stand out because of the way they gradually became accepted by employers and even higher education throughout the late 1980s and early 1990s and have become a durable part of the vocational qualifications landscape, despite the indifference 
or even hostility of successive governments (Williams 1999).

What all of these broad vocational qualifications had in common was that they were reactive to wider trends and structures and were introduced to respond to rising levels of full-time post-16 participation in a divided qualifications system (Hodgson and Spours 1997). GNVQ in the early 1990s, for example, was designed to provide an alternative to A Levels, particularly in school sixth forms. At the time that the GNVQ was being introduced, the Conservative Government was trying to restrict participation in the academic track by closing down innovative modular A Level programmes, such as the Wessex Project (Rainbow 1993), by restricting the amount of coursework in both GCSEs and A Levels and by introducing tiered ${ }_{\mathrm{vii}}$ GCSE examinations (Spours 1993). Given this policy context, practitioners reacted with pragmatic enthusiasm to the GNVQ because they needed post-16 awards for learners who were deemed unsuitable for participating in what was intended to be a more restrictive academic track (Williams 1999).

At the same time, practitioners had to deal with an extremely complex NVQ-inspired assessment regime (OfSTED 1994, SCAA 1996, Ecclestone 2000), which contributed to very low GNVQ completion rates compared with BTEC awards (Spours 1995, Robinson 1996, Carvel 1997). As a result of these difficulties, the fledgling GNVQ went through a number of reviews during the mid-1990s (e.g. NCVQ et al. 1995, Capey 1995, Dearing 1996), the effects of which were to make them more manageable to deliver.

Consequently, by the end of the decade, GNVQs had managed to establish for themselves a niche in 16-19 education and, in a slightly different form - Part 1 GNVQs - began to be introduced into the 14-16 curriculum. In compulsory education they earned a reputation not only for providing practical learning for young people alienated by a traditional curriculum (OFSTED 1996), but also for offering accessible GCSE equivalent 
qualifications that counted in performance tables. This too proved popular with schools.

The most recent newcomer to situate itself within the broad vocational suite of qualifications for full-time 16-19 year olds was the Advanced Vocational Certificate of Education (AVCE), introduced in 2000 as part of what became known as the Curriculum 2000 reforms $_{\text {viii }}$. For 14-16 year olds, the Government also developed GCSEs in Vocational Subjects. AVCEs were a response to criticisms of GNVQ standards and were situated much closer to academic qualifications than either GNVQ or BTEC awards. This location, the Government hoped, would ensure greater parity of esteem between vocational and academic qualifications. AVCEs, designed as vocational equivalents to A Levels, turned out to be more 'academic' than GNVQs, although this did not make them any more popular (Hodgson and Spours 2003). In fact, AVCEs made very little headway, particularly in further education colleges, due to their lack of vocational content and because their assessment requirements made it more difficult for learners to achieve high grades than in equivalent subjects offered as Advanced Subsidiary (AS)/A2 A Level qualifications. Many colleges quickly reverted to the more familiar BTEC National Diplomas (Hodgson and Spours 2003).

Broad vocational qualifications have, over the last 20 years, thus occupied what might be termed the middle track. In this location they have experienced a mixture of success and failure. Their successes include being regarded as 'motivational' qualifications for the disengaged (Williams 1999, Bathmaker 2001), contributing to full-time 16-19 participation rates and providing a relatively small but significant alternative route into certain parts of higher education. For policy-makers and practitioners content to see broad vocational qualifications play their niche role in a divided system, this might be success enough. 
However, for those not satisfied with our 'medium participation and achievement system' (Hodgson and Spours 2004), and this includes the Government (DfES 2005a), broad vocational qualifications still constitute a prime site for further reform. This being the case, it is worth reflecting on five significant weaknesses of these awards, as well as the three strengths identified above.

First, they have never been able to escape the shadow of A Levels. The most capable learners continue to take these awards and the very success of broad vocational qualifications in their 'motivational' role means that they are seen as an 'alternative' curriculum (Spours 1997, Williams 1999). Second, GNVQs and AVCEs were designed for post-16 programmes in schools and colleges and they have singularly failed to articulate with apprenticeships and work-based learning, another potential source of prestige (FEDA/IOE/Nuffield 1997). BTEC National awards, which were not government designed, proved to be an exception because they slowly evolved with greater employer and practitioner involvement. The third weakness concerned assessment. Both GNVQs and AVCEs became weighed down by NVQ competence-derived assessment methodology, contributing to mediocre attainment performance and learner instrumentalism (Bates 1997, Savory et al. 2003, Torrance 2006, Ecclestone 2002, 2006). A related issue for both qualifications, although more prevalent with GNVQ, was constant government interference both with their labelling and with their design; processes which compounded the problem of their low visibility and take-up by learners. Hence their fifth weakness, particularly in the case of AVCE, was their relative lack of recognition by either higher education (Hodgson, Spours and Waring 2005) or employers.

This balance of strengths and weaknesses points to the significant challenges facing Specialised Diplomas. They need to be both motivational and rigorous, to provide 
horizontal and vertical progression routes for 14-19 year olds, to attract the full range of learners, to contain a mix of both general and vocational education and to alter employer and higher education demand for vocational qualifications. The Department for Education and Skills (DfES) (2006b, p.1) reflects these tensions in two recent statements about Specialised Diplomas.

'They have been created to provide a real alternative to traditional education and qualifications'.

'Because of their unique design, Diplomas are equally suitable for the most able pupils preparing for demanding university courses; for young people who find the existing education system doesn't suit them and for those who want to go straight into work after leaving school'.

Unsurprisingly, we argue that this is a tall order for any set of qualifications and particularly those that will continue to occupy a middle track location in the English education and training system. Historical analysis shows that the words 'alternative' and 'most able pupils' have not previously sat comfortably together. The evidence considered in the next section of this paper suggests that Specialised Diplomas may improve the role and function of the middle track, but will not be able to meet the full set of criteria outlined above without becoming part of a much wider set of system reforms, which do not feature in current government policy for 14-19 education and training. 


\section{Specialised Diplomas within the current 14-19 reform agenda}

\section{Policy aims and assumptions}

The major driver behind 14-19 policy in England is the widely accepted desire to raise levels of participation and attainment in order to compare more favourably with international competitors on education and training system performance. In particular, there are concerns about participation at 17+ and raising Level 2 attainment (the level associated with employability in policy discourse). Three key targets related to participation, attainment and engagement are cited in the 14-19 Implementation Plan (DfES 2005b) which, during 2005/6, has been seen as the key policy text in this area:

- increasing attainment by the age of 19 - at Level 2 from 67 per cent in 2004 to at least 70 per cent by 2006 and 72 per cent by 2008 ;

- at Level 3, increasing the number of young people completing apprenticeships by 75 per cent by $2007 / 8$ as compared to $2002 / 3$;

- increasing the number of young people participating in education from 75 per cent now to 90 per cent by 2015 and reducing the proportion of young people not in education, employment or training by 2 percentage points 2010 .

The DfES view is that to meet these targets it will need to change the nature of 14-19 education and training. Policy documents (e.g. DfES 2002, 2003, 2005a) suggest that more young people will stay on in education or training if they can be offered a choice of ways of learning through an alternative vocational curriculum; the basic skills to progress within the 14-19 phase; and collaborative 14-19 institutional arrangements to support a vocational entitlement. Others have looked at the problems of low levels of participation 
and attainment in 14-19 education and training in a different way, which requires a broader set of reforms. They have stressed the importance of removing qualifications divisions, both academic/vocational and pre- and post-16 (Finegold et al. 1990, NCE 1993, Hodgson and Spours 1997, Working Group on 14-19 Reform 2004); the central role of the youth labour market in framing young people's behaviour (Evans et al. 1997, Hayward et al. 2005); and the need for institutional reorganisation to reduce social segregation between schools, colleges and the work-based route (Stanton and Fletcher 2006, Hayward et al. 2006). This latter analysis has led to proposals for a unified qualifications system; licence to practise in the youth labour market and tertiary solutions to 14-19 organisation - all of which currently appear to be unpalatable to this Government.

Given the DfES analysis of the problems within 14-19 education and training, the key concepts it uses to drive policy in this area are 'excellence' and 'standards', 'choice' and 'personalisation', a 'national 14-19 entitlement', a focus on basic skills and provider collaboration. Behind these key concepts lie eight broad assumptions:

1. A better quality education and training system will attract more learners to stay in it - 'for all the improvement in individual schools and colleges, not enough people feel engaged by the education on offer'. (DfES 2005a, p.1)

2. Young people learn in different ways and need to have 'tailored' support, so it is important - 'for all young people to chose a qualifications pathway which suits them' (DfES 2005a, p.2) and a choice of mode of study, whether this be at school, college or in an apprenticeship;

3. All young people need functional skills to Level 2 in English, Maths and ICT - 
'Whichever route young people take, they will have to succeed in the basics of English and Maths, which are so crucial to success in life and at work' (DfES 2005a, p.2)

4. GCSEs and A Levels are 'well understood' and 'internationally recognised', but vocational qualifications constitute a weak link in our system.

5. There will be a wide range of institutions offering provision (FE colleges, sixth form colleges, specialist schools, school sixth forms, national skills academies, academies and 16-19 academies as well as private work-based learning providers) and this will be reinforced by the use of LSC led 'competitions' - 'we are taking important steps to bring in new providers'. (DfES 2005a, para. 3.46)

6. Institutional collaboration is vital because - 'the nature of the 14-19 entitlement makes it evident that no school acting alone will be able to meet the needs of all young people on its roll and very few colleges will be able to offer the full breadth of curriculum on their own.' (DfES 2005a, para 3.1)

7. There needs to be local flexibility in the way that the new provision will be offered - 'the detail of how an entitlement is to be delivered in an area must be decided locally'. (DfESa 2005, para 3.2)

8. Vocational qualifications will be strengthened because of employers' leading role in the design of the new Specialised Diplomas '...we are working with employers to develop new qualifications with practical workplace experience'. (DfES 2005a, p.2) and employers will recognise these new qualifications because they have been involved in determining their content.

There are two main mechanisms for achieving these aims - the creation of a national 14- 
19 Entitlement to be in place by 2013, the centrepiece of which will be the new 14 lines of Specialised Diplomas, and the development of flexible and collaborative local delivery systems. While these two mechanisms are very much inter-related in practice, it is the former which constitutes the focus of this article and which we discuss in more detail below.ix

\section{The Specialised Diplomas - design, purpose and implementation issues $x_{x}$}

As we have seen, at the heart of the national 14-19 Entitlement lie the new 'employerdesigned' Specialised Diplomas of which there will be 14 lines offered at Levels 1-3 (Foundation, Intermediate and Advanced) of the National Qualifications Framework. The DfES intends that Specialised Diplomas should provide 'an exciting, stretching and relevant programme of learning for young people of all backgrounds and abilities' (DfES 2006a, p.3) and should prepare them for life and work. It is claimed that the diplomas will achieve this by their blend of general and applied learning in 'real world environments' (each diploma has to include at least 10 days of learning in a work setting) and the fact that they are designed by both employers and educators.

Each of the diploma lines follows a common template comprising three elements:

- Principal Learning, which is designed to 'develop knowledge, understanding and skills relevant to a broad economic sector, using realistic contexts and leading edge sector relevant materials';

- Additional/Specialist Learning which 'will allow learners to tailor their programme according to their interests and aspirations and may include further specialisation, or complementary studies'; 
- Generic Learning, which 'will ensure that all Diploma students cover common skills essential to successful learning and future employment. It includes personal learning and thinking skills, a project, work experience and maths, English and ICT.' (DfES 2006a, p.10)

The proportions of each of the three elements of the Diploma are different at each of the three levels, with Generic Learning decreasing and Principal Learning increasing from Level 1 up to Level 3. A Level 1 Specialised Diploma is seen as broadly equivalent to 45 GCSEs, Level 2 to 5-6 GCSEs and Level 3 to three A levels, although there will also be a smaller 'Certificate' at Level 3 equivalent to two A Levels. In addition, the content and assessment requirements of each line of diplomas are likely to be different in different lines because relevant Sector Skills Councils (SSCs) have been asked to take a lead in the 14 Diploma Development Partnerships (DDPs), which are responsible for the content of the Specialised Diplomas, and the sectors cover very broad areas.

At the time of writing, Specialised Diplomas are still at a relatively early stage of development. The first five lines - IT, Health and Social Care, Construction and the Built Environment, Engineering, Creative and Media - will be available from September 2008, a further five - Land-based and Environmental, Manufacturing, Hair and Beauty, Business Administration and Finance from September 2009 - from September 2009 and the final four - Public Services, Sport and Leisure, Retail and Travel and Tourism - will be introduced from September 2010. However, even at this point in the policy process a number of fundamental questions arise both about how the Specialised Diplomas will fare in the implementation phase and, more importantly, what their role will be in the future shape of the 14-19 education and training system. Several of the more practical issues raised in this article arise from seminars and in-depth discussions with a wide range of 
practitioners, researchers and policy makers as part of the Nuffield Review of 14-19

Education and Training in England and Wales $\mathrm{x}_{\mathrm{i}}$.

\section{What are their purposes?}

Like GNVQs, the Specialised Diplomas are intended to serve multiple purposes, some of which are in tension with one another. As we have already noted, they are intended to provide programmes of study for disaffected learners; for learners who have failed to reach the $5 \mathrm{~A}^{*}-\mathrm{C}$ benchmark at 16 ; for those wishing to pursue a high-quality employer recognised qualification and for those wanting to prepare for entry to higher education. The recent history of broad vocational qualifications suggests that it is difficult to design a single set of awards to meet this wide range of needs without compromising one or more of its aims. In the case of both GNVQs (FEDA/IOE/Nuffield 1997) and AVCEs (Savory et al. 2003), this led to awards which were neither sufficiently vocational to be highly valued by employers nor sufficiently general to be fully accepted by universities.

In addition, Specialised Diplomas at Levels 1 and 2 are supposed to meet the needs of 1416 year olds still in compulsory education and 16-19 year olds undertaking postcompulsory study. This is likely to give rise to a number of problems. In particular, practitioners have highlighted the issue of learners pursuing vocational specialisation pre16. Learners of this age are not old enough to gain 'licence to practise' awards such as those in childcare, so even if they pass a Level 2 qualification, they are not necessarily ready to go out into the workplace, unlike their post- 16 counterparts. This raises a question about what the function of a sectoral vocational award of this type might be within compulsory education. In addition, if learners undertake sector-specific specialisation pre-16, there is a danger of repetition of study post-16, particularly if they do not progress to the next level. This practical problem has to some extent been 
recognised by the Qualifications and Curriculum Authority (QCA) and it is considering a 'hybrid' Level 1 Specialised Diploma that would offer learners the opportunity to experience more than one vocational area pre-16, thus keeping their options more open at this stage in their education. However, this relatively minor design solution will not address the broader problems of purpose highlighted above.

\section{How popular are they likely to be?}

Historical precedent suggests that the retention of GCSEs and A Levels, which have been accepted as the most prestigious route of study for 14-19 year olds for many years, will mean that the most able learners (and their parents) are likely to continue to opt for these qualifications rather than to choose one of the new Specialised Diplomas. Moreover, if Specialised Diplomas co-exist with tried and tested vocational qualifications such as BTEC Diplomas, and City and Guilds London Institute awards, their popularity is not assured even among those learners wishing to take more applied or vocational study. Currently, awarding bodies are reserving their position on whether to replace their existing awards with the new Specialised Diplomas. There is, therefore, the danger of a repetition of the GNVQ and AVCE experience of a low-status and low-profile award which has to compete with other more tried and tested qualifications and is only partially accepted by higher education and by employers, thus reducing both learner and end-user demand.

\section{Who is designing them?}

The DfES hopes that the 'unique' design of the Specialised Diplomas will make them attractive to learners. However, the design of the new awards has been rushed (the original date for their full implementation has been brought forward from 2013 to 2010), has separated the determination of content, accreditation and assessment and has not 
overtly built upon previously successful vocational qualifications.

The generic template for the Specialised Diplomas was primarily designed by private consultants working for QCA, with very little time for full consultation either with qualifications experts or with practitioners. The designers attempted to incorporate some features of the Tomlinson proposals into the Diploma template but did not make strong use of existing vocational qualifications designs. The DDPs, who were in charge of 'populating' the specialised Diploma generic template with learning outcomes, did not necessarily have the curriculum expertise required for this task and they had to adapt to a pre-determined template which did not always match their sector needs. Meanwhile, awarding bodies, which do have the expertise to design the diplomas, played a marginal role in the initial design, even though they are now expected to develop the specifications for these new awards and possibly to use them to replace their own existing qualifications. QCA, as the regulator, has overall say on the final designs and assessment and, as history suggests, the approach to assessment will have a major bearing on teaching, learning and achievement ${ }_{\mathrm{xii}}$.

The different roles for each of the three parties in the shaping of the new Specialised Diplomas, particularly given the very short timescale for their development, has been fraught with communication problems. Moreover, this new and untried approach to qualifications design, in which bodies representing employment sector interests have been accorded the leading role, risks creating very different Specialised Diplomas in each of the 14 lines, which may restrict horizontal and vertical progression for learners within and across the framework. As Mike Tomlinson pointed out in his Final Report (Working Group on 14-19 Reform 2004), this kind of learner mobility is particularly important at the lower levels of the new Specialised Diploma ladder because this is where learners 
face the greatest barriers to progression under the current qualifications system.

This is not to say, however, that there has been an absence of educational thinking in determining the content of the first five Specialised Diplomas. However, in the context of middle track location, content design in itself will not necessarily produce an award attractive to a very diverse group of learners.

\section{Who will offer them?}

It is clear from the 14-19 Implementation Plan (DfES 2005b) that schools are expected to play a major role in delivering the Specialised Diplomas. It is unlikely, however, that they will be able to offer a large number because they will not have the facilities, despite the capacity-building measures described in the Plan. Colleges, on the other hand, while potentially the obvious providers of the vocational entitlement are, from discussions we have had with senior managers and sector representative bodies, concerned on at least four accounts about fulfilling this role. They are nervous of taking on new qualifications without a strong reputation, having been burnt by the AVCE experience. As a result of dissatisfaction with AVCEs, many colleges have recently gone back to offering BTEC awards and are unlikely to want to switch wholesale to the new Specialised Diplomas. They are also concerned that some of the Specialised Diploma lines, at each of the levels, may attract very small numbers of learners and will make them costly to mount as courses. GNVQs have taught FE colleges that some sector qualifications do not prove popular - Art and Design, Business, Health and Social Care and Leisure and Tourism GNVQs, for example, attracted much larger numbers of learners than any of the other areas (FEDA/IOE/Nuffield Foundation 1997). In addition, colleges are anxious about the very broad nature of each of the 14 lines and the risk of not being able to meet specific learner or employer needs without offering large numbers of costly specialised units. 
Finally, both schools and colleges are concerned about how to ensure enough employer engagement to cover all the work-based elements at all levels of the new awards. This would demand a significant rise in the number of work experience placements available to 14-19 year olds. Evidence submitted to the Nuffield Review of 14-19 Education and Training suggests that schools and colleges are already struggling to fulfil the much less demanding requirements of current vocational qualifications.

\section{Analysing the location of Specialised Diplomas}

The Specialised Diplomas could thus be seen as yet another attempt to strengthen vocational learning for young people, to raise its status and, possibly, to rationalise the plethora of vocational qualifications for this age group. They take forward the programmatic approach to learning and qualifications outlined in the Tomlinson Final Report (Working Group on 14-19 Reform 2004) and appear to constitute a progression ladder of broad vocational full-time provision located between the GCSE/A Level track and apprenticeships, leading to either employment or higher education. While these characteristics look similar to GNVQs, policy documents suggest that Specialised Diplomas are intended to be more vocationally-focused with higher degrees of employer engagement and recognition and it is these features that government is hoping will prove attractive to both young people and end-users. The Government has staked the reputation of Specialised Diplomas on their 'unique design' and the formation of a collaborative network of providers to deliver them. However, it is within the wider context of the 1419 education and training system and reform process that Specialised Diplomas will, arguably, either succeed or fail.

First, as we have argued above, Specialised Diplomas will co-exist with 'traditional' 
GCSEs and A Levels and history suggests that these latter qualifications will continue to attract the most able learners. From the initial specifications of the first five Specialised Diplomas, it appears that the DDPs are aware of this danger and have been designing the content of the Diplomas (particularly in Engineering) to emphasise parity of esteem in order to attract students away from the academic track. At the same time, Specialised Diplomas are seen as a full-time route to apprenticeship but not the qualifications basis of apprenticeship (QCA 2006). Both these design features confirm the middle track location of Specialised Diplomas. This is fuelling an ongoing debate as to the nature of the new awards, centring around the degree to which they will become more general, more applied or more sharply vocational. The latest draft of content of the first five diplomas published in July 2006, possibly with the exception of Construction, looks as if the balance is tilting towards academic/applied rather than vocational/practical, casting doubt over whether these awards will eventually be labelled as vocational qualifications.

Second, there is absolutely no guarantee that employers will recognise Specialised Diplomas to the extent that young people will detect strong labour market signals for these awards. Vocational qualifications currently play a marginal role in labour market recruitment and selection (Keep 2005) and the fact that the relatively new Sector Skills Councils have been involved in determining the content of these new qualifications is likely to cut little ice with employers as a whole.

\section{The future for Specialised Diplomas - niche award or part of a transformed}

\section{4-19 system?}

\section{Middle-track location}

When she came into post as Secretary of State for Education and Skills in 2004, Ruth Kelly 
made two inter-related assumptions about 14-19 education and training - A Levels and GCSEs were untouchable because they were an education brand recognised by parents, employers and higher education; and the main problem with the English education and training system lay with vocational education. Immediately, the broad scope of discussion about reform of the phase, led by Mike Tomlinson's Working Group on 14-19 Reform, was narrowed to focus on vocational education taking place in schools and colleges and separate from GCSEs, A Levels and apprenticeships. We have argued that because of these political assumptions and policy actions, Specialised Diplomas appear destined to become a full-time vocational route occupying a middle track between a dominant A Level route and a smaller Apprenticeship system. In this location, they risk the fate of their predecessor qualifications successful to a degree as an applied alternative to GCSEs and A Levels, but hardly transformative of 14-19 education and training.

It is possible that Specialised Diplomas could form a larger middle track if they were able to replace the vocational qualifications (e.g. AVCEs, GNVQs, BTEC and NVQ equivalents) that currently occupy this space. However, this 'locational' clarity is not assured because awarding bodies, such as Edexcel and CGLI, are only likely to surrender their tried and tested qualifications if Specialised Diplomas subsume some of the specialist vocational functions of these current qualifications. It is almost certain that Specialised Diplomas will replace the more school-based GNVQ, AVCE and GCSEs in vocational subjects but it is not at all certain that they will replace the more sharply vocational BTEC and CGLI awards that currently straddle college-based and work-based learning programmes and, in some cases, serve as the technical certificate component of apprenticeship frameworks.

\section{Confusions of purpose in a rushed policy process}

The ability of Specialised Diplomas to offer a high degree of vocational specialisation is thus in doubt. Designed across 14 broad sectoral lines, Specialised Diplomas do not have the range of work-based content offered by many current vocational qualifications.

Moreover, there is a sharp debate taking place behind the scenes as to their purpose and 
orientation. Like their predecessor broad vocational qualifications, Specialised Diplomas are being designed to provide progression to both further study and to work and their middle-track location means that they risk being pulled in different directions. Policy espousal has projected them as vocationally distinct, meeting employer needs and convergent with the desires of some learners for a more practical curriculum. Policy practice, as we have seen, reflects a different process taking place. Specialised Diplomas are being pulled away from a strongly vocational trajectory by the status of unreformed A Levels and their distinction from apprenticeships. Moreover, the issue of balance between general and vocational learning has been made more acute by introducing Specialised Diplomas into compulsory education at Key Stage $4_{\text {xiii }}$, where general education needs are most pronounced. The outcome may well be that Specialised Diplomas will become 'neither fish nor fowl' in the eyes of post-16 learners and endusers - not really equivalent to traditional A Levels but not sufficiently vocational to meet vocational 'licence to practise' requirements.

Problems of location and purpose are being compounded by a rushed and less than transparent policy process. Having rejected the central proposal from the Tomlinson Final Report - a unified and inclusive diploma system covering the whole of 14-19 education and training - the Government felt the need to have a driving proposal in the 14-19 White Paper - the Specialised Diplomas - which reflected some of the Tomlinson ideas. This was combined with the need to convince employers that it was serious about meeting their 'needs' - hence the move to involve them more fully in designing entirely new vocational qualifications with an untried qualifications design process. However, in failing to recognise the value of long-standing vocational qualifications, such as BTEC National and CGLI awards, and to build on their success, the Government may be taking significant risks. It may get the designs wrong and, in the short-term at least, increase 
rather than rationalise the already large number of vocational qualifications; a process likely to cause further confusion amongst end-users and to lower the profile of the new diplomas.

\section{Supply and demand issues}

These three problems - middle-track location, multiplicity or even confusion of purpose and a rushed reform process - are likely to lead to significant status problems as Specialised Diplomas struggle to establish themselves in a crowded qualifications landscape, still under the shadow of A Levels and with unchanged employer recruitment practices. The Government is depending upon the design of the new diplomas and employer involvement in this process, together with the development of collaborative provider partnerships, to boost learner demand and post-16 participation. We have argued that this supply-side strategy may not be enough because the prognosis for Specialised Diplomas will be fundamentally determined by learner and employer demand for the new qualification and neither of these is assured for what is likely to be a new, untried, broad vocational qualification. Simply, too much is being expected of a narrow supply-side initiative.

\section{Whole-system not part-system reform}

At this point in the reform process, we conclude that the fate of Specialised Diplomas will be determined more by their context than by their content. The Government has staked a great deal on this new qualification but has done very little to change the context into which it will be introduced. This, in our view, points to the need for more radical wholesystem reform. The 14-19 reform process will need to avoid dependence on what we have characterised as a divided supply-side strategy and to seek, instead, a more 
expansive synergy of supply-side and demand-side policies.

On the supply side, whole-system reform would mean, for example, the development of a unified and comprehensive 14-19 diploma system, such as that proposed in the Tomlinson Final Report (Working Group on 14-19 Reform 2004), which would provide a mix of more open $\mathrm{xiv}_{\mathrm{x}}$ and more specialised diploma programmes to meet the needs of all learners throughout the 14-19 phase. A Levels, GCSEs, other major awards for 16-19 year olds and apprenticeships would all be absorbed into the diploma system, rather than being located separately and would thus obviate the need for arguments about 'parity of esteem'. For the 14-16 age group, such a system would provide more general programmes of study pre-16 at Entry, Level 1 and Level 2, allowing for sharp vocational, practical and applied experiences, but avoiding the problems of early sectoral or occupational specialisation highlighted earlier.

However, if 14-19 reform is going to lever up participation, policy would have to go further than a comprehensive approach to supply-side changes and would need to address issues of employer demand (Keep 2005, Hayward et al. 2005) and post-16 organisation (Hodgson and Spours 2004, Stanton and Fletcher 2006). A broader range of reform synergies is required to shift the education and training system into a new gear. This strategy is more difficult to deliver in the short-term because it involves widespread regulatory and organisational change but, in our view, this approach should be openly discussed as part of the debate on the 14-19 phase.

In the meantime, serious consideration needs to be given to the Review of A Levels in 2008, outlined in the 14-19 Implementation Plan, and what this means for the role of 
diploma programmes in 14-19 education and training in England. Here, it is possible to view the current reform effort around Specialised Diplomas in two ways. The first is to see the new qualifications, as the Government presently does, as 'alternatives' to academic study and thus broadly equivalent to current broad vocational qualifications. The second, is to view them as precursors of a comprehensive system of diplomas designed to shape the curriculum and accredit programmes embracing both academic and vocational education. We have argued that the first interpretation is beset by contextual and structural problems that will undermine learner and employer demand. The second is, arguably, a more viable course, because it changes the context for diplomas to succeed, although it will mean challenging GCSEs and A Levels in their role as high status separate qualifications and this is likely to present political difficulties. However, if the Government were to adopt the second perspective in the approach to the 2008 Review of A Levels and the new awards were seen as diploma precursors for all learners in the 1419 phase, rather than alternatives for those deemed unable to succeed in academic qualifications, Specialised Diplomas might just be rescued from the mire of the middle track. 


\section{REFERENCES}

Bates, I. (1997) Problematizing 'empowerment' in education and work: an exploration of the GNVQ. Occasional Paper No. 7., School of Education, University of Leeds.

Bathmaker, A-M. (2001) 'It's the perfect education': Lifelong learning and the experience of Foundation-level GNVQ student,' Journal of Vocational Education and Training, 53 (1), $81-100$

Capey, J. (1995) GNVQ Assessment Review (London: National Council for Vocational Qualifications).

Carvel, J. (1997, 26 August) Tougher testing for vocational courses The Guardian, 26 August.

Dearing, Sir Ron (1996) Review of Qualifications for 16-19 Year Olds. (London: Schools' Curriculum and Assessment Authority).

Department for Education/Employment Department/Welsh Office (1991) Education and Training for the Twenty-First Century. (London: HMSO)

Department For Education and Skills (DfES) (2002) 14-19 Education: extending opportunities, raising standards. (London: DfES).

DfES (2003) 14-19: Excellence and Opportunity: government response to the 14-19 Green Paper. (London: DfES).

DfES (2005a) 14-19 Education and Skills. (London: DfES).

DfES (2005b) 14-19 Implementation Plan. (London: DfES).

DfES (2006a) The Specialised Diploma Gateway. (London: DfES).

DfES (2006b) Specialised Diplomas - your questions answered. (London: DfES). (www.dfes.gov.uk/14-19/documents/DfESDiplomasJuly06.pdf) Accessed 20 September 2006

Ecclestone, K. (2000) 'Bewitched, bothered and bewildered': a policy analysis of the GNVQ assessment regime, Journal of Education Policy, 15 (5), 539-558.

Ecclestone, K. (2002) Learning Autonomy in Post-16 Education: the politics and practice of formative assessment (London: Falmer/Routledge)

Ecclestone, K. (2006) Assessment in post-compulsory education: Paper 2: commitment and comfort zones: purposes and practices of formative assessment in post-16 programmes. Paper presented to the British Educational Research Association, University of 
Warwick, 6-9 September.

Evans, K., Hodkinson, P., Keep, E., Maguire, M., Rainbird, H., Raffe, D., Senker, P. and Unwin, L. (1997) Working to Learn (London: Institute of Personnel and Development).

Finegold, D., Keep, E., Miliband, D., Raffe, D., Spours, K. and Young, M. (1990) A British Baccalaureate: overcoming divisions between education and training. (London: IPPR).

Further Education Development Agency/Institute of Education/Nuffield (1997) General

National Vocational Qualifications in the Further Education Sector in England.

National survey report. (London: FEDA)

Hayward, G., Hodgson, A., Johnson, J., Oancea, A., Pring, R., Spours, K., Wright, S. and Wilde, S. (2005) Annual Report of the Nuffield 14-19 Review 2004-5. (OUDES: University of Oxford).

Hayward, G., Hodgson, A., Johnson, J., Keep, E., Oancea, A., Pring, R., Spours, K., Wright, S. and Wilde, S. (2006) Annual Report of the Nuffield 14-19 Review 2005-6. (OUDES: University of Oxford).

Higham, J. and Yeomans, D. (2006) Emerging Provision and Practice in 14-19 Education and Training. A Report on the Evaluation of the Third Year of the 14-19 Pathfinder Initiative. DfES Research Report RR737. (Nottingham: DfES).

Hodgson, A. and Spours, K. (eds) (1997) Dearing and Beyond: 14-19 Curriculum, qualifications and framework (London: Kogan Page).

Hodgson, A. and Spours, K. (2003) Beyond A Levels: Curriculum 2000 and the reform of 1419 qualifications (London: Kogan Page.)

Hodgson, A. and Spours, K. (2004) Reforming 14-19 learning: towards a new comprehensive phase of education. New Economy, 11 (4), 217-223.

Hodgson, A., Spours, K. and Waring, M. (2005) Higher education, Curriculum 2000 and the future reform of 14-19 qualifications in England, Oxford Review of Education, 31 (4), 479-496.

Keep. E. (2005) Reflections on the curious absence of employers, labour market incentives and labour market regulation in English 14-19 policy: first sign of a change in direction?, Journal of Education Policy, 20 (5), 533-553.

National Commission on Education (1993) Learning to Succeed: a radical look at education today and a strategy for the future - Report of the Paul Hamlyn Foundation (Oxford: Heinemann).

NCVQ/BTEC/CGLI and RSA (1995) GNVQ Quality Framework (London: NCVQ) 
Office for Standards in Education (OFSTED) (1994) GNVQs in Schools 1993/94. (London: HMSO)

OFSTED (1996) Part One General National Vocational Qualifications Pilot Interim Report 1995/96. (London: HMSO)

Qualifications and Curriculum Authority (QCA) (2006) The Specialised Diploma:

Qualification structure. (London: QCA)

Raffe, D., Brannen, K., Fairgreve, J. and Martin, C. (2001) Participation, inclusiveness, academic drift and parity of esteem: a comparison of post-compulsory education and training in England, Wales, Scotland and Northern Ireland. Oxford Review of Education, Vol. 27 (2), 173-203

Rainbow, B. (1993) Post-compulsory education: a national certificate and diploma framework, in Further Education Unit (ed.), Discussing Credit: A collection of occasional papers relating to the FEU proposal for a Post-16 Credit Accumulation and Transfer Framework. (London: FEU)

Robinson, P. (1996) Rhetoric or reality? Britain's new vocational qualifications. Centre for Economic Performance, London School of Economics.

Savory, C. Hodgson, A. and Spours, K. (2003) The Advanced Vocational Certificate of Education: a general or vocational qualification? Broadening the Advanced Level Curriculum. IOE/Nuffield Series no. 7. Institute of Education, University of London,

Schools Curriculum and Assessment Authority (1996) Review of Qualifications for 16-19 Year Olds. (London: SCAA)

Spours, K. (1993) The recent background to qualifications reform in England and Wales, in Richardson, W., Woolhouse, J. and Finegold, D. (eds), The Reform of Post-16 Education and Training in England and Wales (Harlow: Longman).

Spours, K. (1995) The strengths and weaknesses of GNVQs: principles of design. Working Paper no. 4. Learning for the Future Project, Institute of Education and University of Warwick.

Spours, K. (1997) 'GNVQs and the future of broad vocational qualifications.' In Hodgson, A. and Spours, K. (eds) Dearing and Beyond: 14-19 Curriculum, qualifications and frameworks. (London: Kogan Page).

Stanton, G. and Fletcher, M. (2006) 14-19 institutional arrangements in England - a research perspective on collaboration, competition and patterns of post-16 provision. Paper prepared for Nuffield Review of 14-19 Education and Training Seminar, Making Sense 
of 14-19 Policy Development in England and Wales, Nuffield Foundation, 12 July 2006.

Torrance, H. (2006) 'Assessment in post-compulsory education: Paper 4: Assessment as learning? How the uses of explicit learning objectives and assessment criteria can come to dominate learning'. Paper presented to the British Educational Research Association, University of Warwick, 6-9 September.

Williams, S. (1999) Policy tensions in vocational education and training for young people: the origins of general national vocational education, Journal of Education Policy, 14 (2) 151-166.

Wolf, A. (2002) Does Education Matter? Myths about education and economic growth.( London: Penguin).

Working Group on 14-19 Reform (2004) 14-19 Curriculum and Qualifications Reform: final report of the Working Group. (London: DfES). 


\section{ACKNOWLEDGEMENTS}

The authors wish to acknowledge the generous support of the Nuffield Foundation for The Nuffield Review of 14-19 Education and Training in England and Wales. This article was developed as part of the work of the Review. In addition, we would like to thank Geoff Hayward and Geoff Stanton for their constructive suggestions for improvement of an earlier version of the article.

\section{NOTES ON AUTHORS}

Ann Hodgson is a Reader in Education at the Institute of Education, University of London

Ken Spours is a Reader in Education at the Institute of Education, University of London 
NOTES 
${ }^{\mathrm{i}}$ IT, Health and Social Care, Engineering, Creative and Media, Consturction and the Built Environment, Land-based and Environmental, Manufacturing, Hair and Beauty, Business Administration and Finance, Hospitality and Catering, Public Services, Sport and Leisure, Retail, Travel and Tourism

ii 'Academic drift' here refers to the process whereby vocational qualifications take on features of their academic counterparts in order to raise their status in a divided qualifications system (See Hodgson and Spours 2003). Others, such as Raffe et al. ( 2001) and Wolf (2002) use the term to refer to the way that young people opt to remain in the academic route rather than choosing vocational options when the latter are perceived as of lower status.

iii Working Group on 14-19 Reform (2004)

${ }^{\text {iv }}$ Some vocational education policies in the UK cover England, Wales, Scotland and Northern Ireland (e.g. credit frameworks). Currently, however, Specialised Diplomas are part of 14-19 policy only in England. Wales is reserving its judgement on whether to introduce these awards (see Hayward et al. 2006, Chapter 2).

' By this term we mean a 14-19 pathway that is neither 'academic' (GCSEs and A Levels) nor strongly vocational/work-based (NVQs/Apprenticeships) and thus sits in the middle of the three main routes through 14-19 education and training in England.

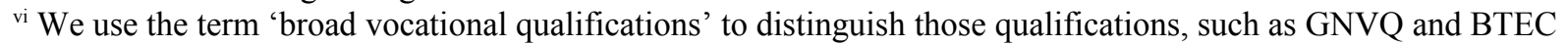
National (and now Specialised Diplomas), which are composite awards that constitute either the whole or a substantial part of full-time learner programmes, from 'vocational qualifications', such as NVQs, which are usually smaller, are mainly offered to part-time learners as part of a predominantly work-based programme.

${ }^{\text {vii }}$ Tiered GCSEs refers to the introduction of a number of different levels of papers spanning different grade profiles into what had been a single examination.

viii Curriculum 2000 refers to the reform of the major full-time qualifications for 16-19 year olds and the introduction in 2000 of modular AS/A2 qualifications, replacing traditional A Levels, AVCEs or Applied A Levels in some subject areas and a new Key Skills Qualification for all 16-19 year olds (see Hodgson and Spours 2003 for a full account of the Curriculum 2000 reforms).

${ }^{\text {ix }}$ See Hayward et al. 2005 and 2006 Annual Report of the Nuffield 14-19 Review for a more detailed discussion of the role of collaborative local delivery systems in 14-19 reform

${ }^{\mathrm{x}}$ Our comments in this section are based on a snapshot at a particular point in the reform process that is changing rapidly.

xi The Nuffield Review of 14-19 Education and Training in England and Wales was launched in October 2003 and will run until August 2009. The Review is led by a Directorate of Richard Pring and Geoff Hayward from the University of Oxford's Department of Educational Studies; Ann Hodgson and Ken Spours from the Institute of Education, University of London; Jill Johnson from the Universities and Colleges Admissions Service; and Ewart Keep and Gareth Rees from the University of Cardiff. It is both independent of government and aims to take a comprehensive view of 14-19 education and training. The work of the Review is available online at: www.nuffield14-19review.org.uk.

xii The modes, amount and balance of assessment were problematic in both GNVQs (Capey 1995, Dearing 1996, Ecclestone 2002) and AVCEs (Savory et al. 2003) so the impact of this aspect of the new Specialised Diplomas should not be underestimated. However, a discussion of assessment within the Specialised Diplomas cannot be a focus of this article because the assessment model is still not determined

xiii Key Stage 4 is the name given to the final two years of secondary schooling for 14-16 year olds.

${ }^{\text {xiv }}$ Open was the term used in the Tomlinson Final Report to denote diplomas made up of a variety of subjects without any clear area of specialisation. 'We do not, however, propose to label any individual diploma awarded to a young person as 'specialised'. Every diploma would either be 'open' or be labelled according to the area of specialisation.' (Working Group on 14-19 Reform 2004, p.24) 